\title{
Student Science Process Skills through the Application of Computer Based Scaffolding assisted by PhET Simulation
}

\author{
Affa Ardhi Saputri \\ Fakultas Sains dan Teknologi Universitas Islam Negeri Walisongo Semarang \\ *Correspondence email: affaardhi@walisongo.ac.id
}

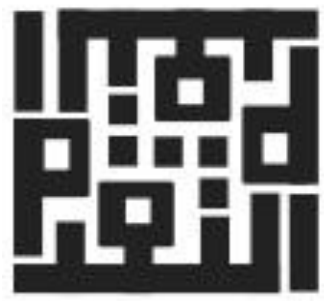

ISSN: $1979-4703$ (p)

ISSN: 2527-9726 (e)

\section{Article history:}

Received 7 May 2021

Accepted 30 May 2021

Published 30 June 2021

Keywords:

Computer-Based

Scaffolding, PhET

Simulation, Science

Process Skills.

\begin{abstract}
A B S T RACT
Basic physics practicum learning through virtual laboratories is less than optimal in developing students' science process skills. This study reveals the results of improving students' science process skills based on the application of computer scaffolding assisted by PhET simulation. This study uses a quantitative approach with a sample of 14 students through purposive sampling technique. The research stages consist of introduction, implementation, and evaluation. Collecting data through interviews, tests, and observations. Data analysis using the $\mathrm{N}$-gain test. The results showed an increase in students' science process skills on several indicators with various categories. The indicator is observing 0.49 (medium category), formulating hypotheses 0.34 (medium category), carrying out experiments 0.39 (medium category), data interpretation and analysis 0.42 (medium category), communicating 0.33 (medium category), and concluded 0.29 (low category). Computer-based scaffolding with PhET simulation is an online learning solution that can also be collaborated with offline learning to improve students' science process skills.
\end{abstract}

\section{Introduction}

The Covid-19 pandemic that hit the world caused a change in the order in the education sector (Siahaan 2020). Online learning, which began in March 2020, left several problems, especially in practicum courses. The majority of practicums are carried out using simple tools and materials. However, the obstacles faced are the limitations of the tools and practicum materials that are around.
Education practitioners complained about the difficulty of carrying out online practicum activities during the Covid-19 pandemic due to limited tools and materials (Noor et al. 2020; Sholikah et al. 2020). This is reinforced by the results of interviews with lecturers and students on online practicum learning evaluations. Students do not have sufficient tools and materials following the titles of basic physics practicum. Students also object to buying equipment that is quite expensive 
to carry out independent practicum activities at home. By utilizing various virtual laboratory applications/software, the virtual practicum is a solution to overcome the constraints of limited tools and simple practicum materials at home.

The virtual laboratory is a product of the current development of digital information technology. The use of various applications, including virtual laboratories, is a logical consequence of adapting to information and communication technology development. The rapid development in information technology has led to a paradigm shift in various fields, including education. Along with the development of technology and information, there is a shift in learning media from print to digital. Various digital learning media were developed in response to the progress of technology and information development, such as digital modules (Yusro and Purwito 2021), the use of student assistance scaffolding with digital technology (Saputri and Wilujeng 2017; Wu, Chen, and Chen 2018; Dwi et al. 2020), and the use of virtual laboratories such as PhET Simulation (Haryadi and Pujiastuti 2020).

The use of virtual laboratories in online learning still leaves some problems. Based on interviews with three lecturers who support practicum courses, several problems that arise in the implementation of virtual laboratories can be identified. The lack of skill of students in carrying out practical procedures, students' lack of understanding of the method of error, and low skills of students' science processes are the problems identified during the implementation of online practicums. In addition, mastery of student science process skills is low during the implementation of online learning with virtual laboratories (Syazali, Rahmatih, and Nursaptini 2021). Practicum or experiment is one way to achieve science process skills.

Fundamental physics practicum is closely related to observation, measurement, experimentation, and experimentation to prove the concept or attempt to solve problems. Based on the characteristics of these courses, students' science process skills are essential to be trained and developed. Science process skills include solving a problem, including observing, classifying, measuring, predicting, communicating, and concluding (Samosir and Gurning 2020; Darmaji et al. 2020).

Science process skills support 21stcentury skills, namely critical thinking, collaboration, communication, and creativity. Science process skills affect the achievement of critical thinking skills (Fitriyanto et al., 2019). Science process skills are how a person understands, researches, and reveals natural phenomena. The process skill indicators consist of cognitive, psychomotor, and affective aspects (Siswono 2017). Indicators of science process skills include observing, classifying, predicting, interpreting, formulating hypotheses, planning practicums, using tools and materials correctly, applying concepts, communicating, and concluding (Rustaman 2005). Based on these indicators, communication is one of the indicators in science process skills. Thus, science process skills play a role in achieving 21 st-century skills in the realm of communication skills. 
Science process skills will eventually shape and build students' knowledge and concepts (Lestari and Diana 2018). In addition to forming the structure of student knowledge concepts, science process skills are also important to be trained and developed as a provision for students to face real problems in social life (Rohman and Ain 2019). This study uses indicators of science process skills, including observing, formulating hypotheses, carrying out experiments, interpreting and analyzing data, communicating, and concluding. The importance of achieving students' science process skills is to innovate in implementing online practicums to improve students' science process skills (Syazali, Rahmatih, and Nursaptini 2021). The innovation that can be applied is to integrate a virtual laboratory with a scaffolding approach.

Scaffolding is a learning approach that allows a person to solve problems, carry out a task, and achieve a certain goal that has been set (Wood, Bruner, and Ross 1976; Brian and Iris 2014). Scaffolding is divided into three types, namely: one-toone scaffolding (scaffolding one on one), computer-based scaffolding (computerbased scaffolding), and peer scaffolding (peer-to-peer scaffolding). Computerbased scaffolding is support or assistance through computer devices for students to acquire certain skills to complete tasks beyond their abilities (Belland 2017). There are three levels or levels in the scaffolding approach. The three levels are environmental provision, explaining, reviewing, restructuring, and developing conceptual thinking (Dasilva et al. 2019).
The first level in the scaffolding approach is the environmental provision. The lecturer conditions and prepares a learning environment for students (Dasilva et al. 2019). Lecturers prepare to learn resources, learning media, enthusiasm, and motivation for students. The second level is explaining, reviewing, restructuring, namely explaining, reviewing, and restructuring (Dasilva et al. 2019). Explaining, the lecturer is involved in direct interaction with students at this stage. Reviewing, students are given the opportunity to see, touch, and explain concepts based on their perceptions. The lecturer then assists in restructuring, namely, interpreting the concepts put forward by students and explaining them in a better and orderly language. The third level is developing conceptual thinking, namely developing conceptual thinking (Dasilva et al. 2019). Lecturers give more abstract assignments to students. In this activity, students also develop all representational tools that have been studied previously.

The scaffolding approach has also improved science process skills (Haryati et al. 2020; Lee, Heo, and Park 2019). Students' science process skills can be improved by integrating a scaffolding approach to learning by optimizing virtual laboratories. One of the familiar and complete virtual laboratory media is PhET simulation. PhET simulation can be accessed easily and free of charge by students not to burden students financially. In addition, most of the basic physics practicum titles are available in the PhET simulation application. Students also have experience in the previous semester's practicum using PhET simulation. Several studies have 


\section{At-Taqaddum}

Vol. 13 No. 1 (2021) Pg. 21-38

developed subject-specific pedagogy (SSP) with a scaffolding approach in PhET simulation (Utami et al. 2019; Dasilva et al. 2019). Thus, PhET simulation can be integrated with a scaffolding approach to improving students' science process skills.

This study describes the application of computer-based scaffolding with the help of PhET simulation and analysis of students' science process skills. Science process skills are closely related to experimental and practical activities (Lestari and Diana 2018; Zulaeha, Darmadi, and Werdhiana 2014). The implementation of practicum during the covid-19 pandemic and the new normal era which is carried out online, is considered less able to hone students' science process skills. This study applies a computer-based scaffolding approach to answer the fulfillment of learning needs as an adaptation of the development of science and technology. Computer-based scaffolding assisted by PhET simulation is a solution to improve science process skills in implementing online practicum learning (Dasilva et al. 2019). The three levels or levels of scaffolding are integrated into learning with the orientation of achieving science process skills, including observing, formulating hypotheses, carrying out experiments, interpreting and analyzing data, and concluding. Thus, the online implementation of basic physics practicum learning can still be adequate for developing and improving students' science process skills. Computer-based scaffolding assisted by $\mathrm{PhET}$ simulation is applied to basic physics practicum learning to improve students' science process skills in electric-magnetic practicum, parallel-capacitor series practicum, and parallel-resistor series circuit practicum.

\section{Research Method}

This research uses a descriptive quantitative method. The sample in this study was 14 physics students who took basic physics practicum lectures. The sample was determined using the purposive sampling technique. Data collection techniques used are interviews, tests, and observations. The stages of the research carried out are an introduction, implementation, and evaluation. The research was carried out for four months, starting in January-May 2021. Figure 1 shows the stages of the research carried out. 


\section{Figure 1.}

The flow of Introduction, Implementation, and Evaluation in Research

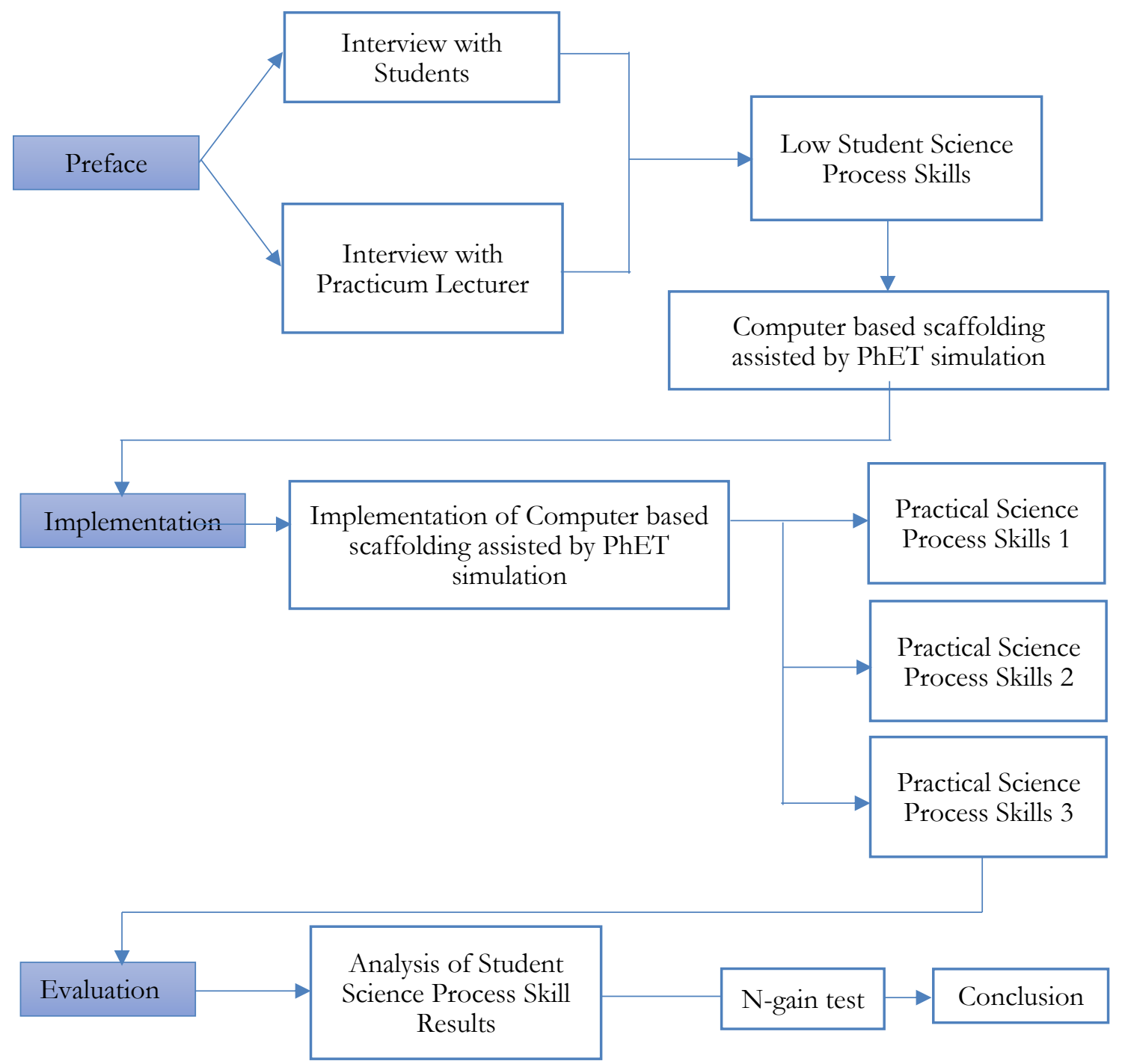

The preliminary stage is carried out by conducting interviews. Interviews were conducted on students who had carried out online practicum learning and had used PhET simulation. In addition to conducting interviews with students who have carried out practicum lessons online, interviews were also conducted with lecturers in charge of basic physics practicum courses. At this stage, problems were found in basic physics practicum lectures. The problem in implementing fundamental physics practicum online is the low level of students' science process skills. Furthermore, to solve these problems, planning is carried out by implementing computer-based scaffolding assisted by 
PhET simulation in Basic Physics II Practicum lectures.

The implementation stage is computerbased scaffolding assisted by PhET simulation in the Basic Physics II Practicum lecture. Data collection was carried out on the achievement of science process skills, including indicators: observing, formulating hypotheses, carrying out experiments, interpreting and analyzing data, communicating, and concluding. Science process skills were measured three times in three practicum titles. The implementation of computerbased scaffolding assisted by PhET simulation follows the matrix as shown in Table 1. The titles of the practicums carried out by students in succession are electric-magnetic practicum, parallelcapacitor series circuit practicum, and parallel resistor series circuit practicum. The implementation of computer-based scaffolding assisted by PhET simulation was carried out for six meetings, namely two meetings for each practicum title.

Table 1.

Matrix of Application of Computer Based Scaffolding assisted by PhET Simulation and Aspects of Student Science Process Skills

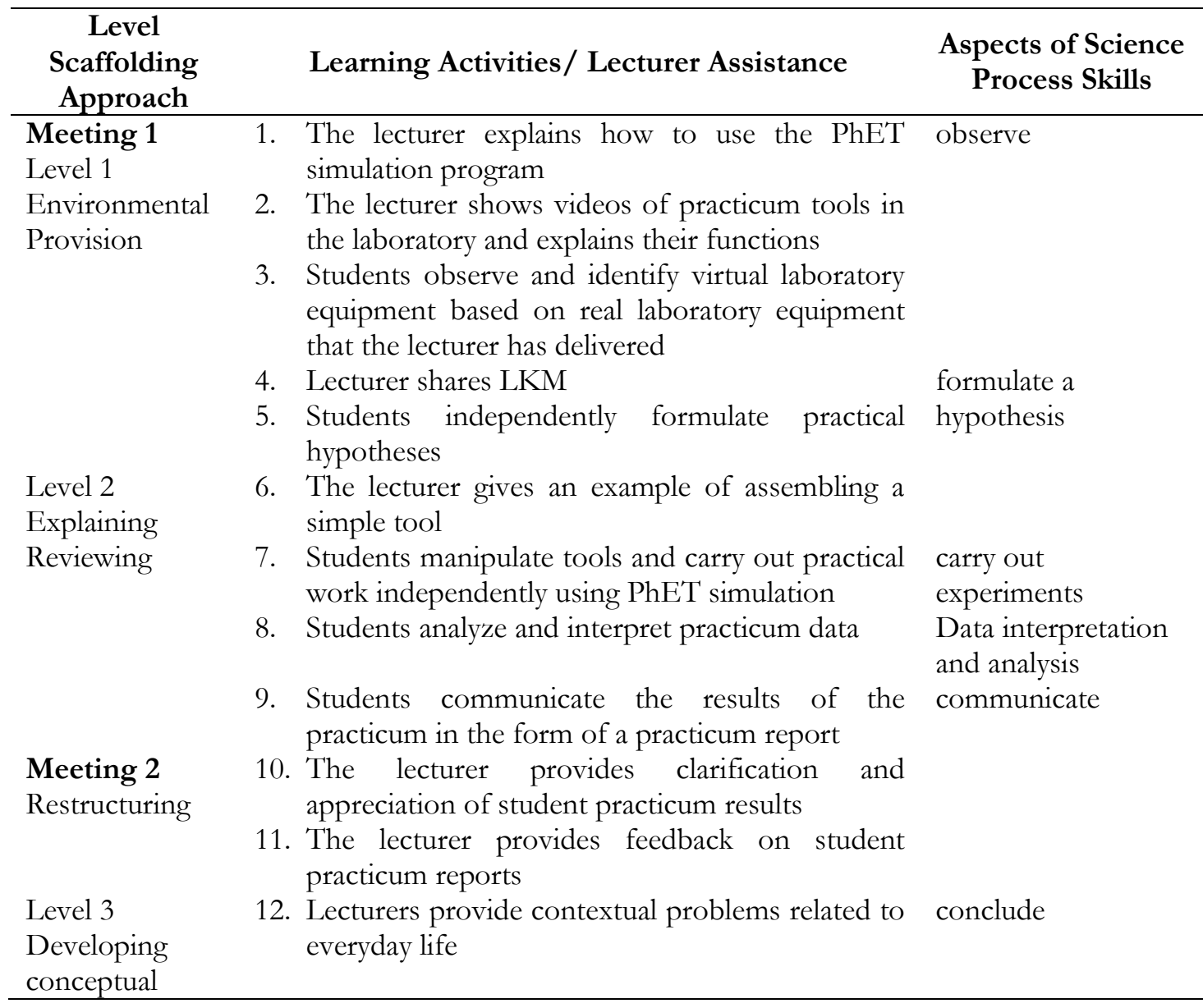


thinking

13. Students conclude the results of the practicum and draw conclusions based on applications in everyday life.

The evaluation was carried out by analyzing data on the achievement of students' science process skills indicators for three practical activities. The instrument used is a science process skills test which is given after completing the practicum. The results were averaged and tested for improvement between the title of practicum 1 to practicum 2, the title of practicum 2 to practicum 3 , and the increase between the title of practicum 1 to the title of practicum three by using the $\mathrm{N}$-gain test. A more detailed analysis of the data used can be seen in Table 2. The normalized gain value categories are divided into three categories, as presented in Table 3. The final results obtained conclusions regarding the application of computer-based scaffolding assisted by PhET simulation to improve students' science process skills accompanied by improvement analysis for each indicator.

\section{Table 2.}

Data Analysis of Science Process Skills

\begin{tabular}{cc}
\hline N-gain & Data analysis \\
\hline Practicum of 1-2 & $\langle g\rangle=\frac{\left\langle K P S_{2}\right\rangle-\left\langle K P S_{1}\right\rangle}{100 \%-\left\langle K P S_{1}\right\rangle}$ \\
Practicum of 1-2 & $\langle g\rangle=\frac{\left\langle K P S_{3}\right\rangle-\left\langle K P S_{2}\right\rangle}{100 \%-\left\langle K P S_{2}\right\rangle}$ \\
Practicum of 1-2 & $\langle g\rangle=\frac{\left\langle K P S_{3}\right\rangle-\left\langle K P S_{1}\right\rangle}{100 \%-\left\langle K P S_{1}\right\rangle}$ \\
\hline
\end{tabular}

Table 3.

Categories of Normalized Gain Values (Hake 1999)

\begin{tabular}{cc}
\hline Category & Intervals \\
\hline$\langle g\rangle \geq 0,7$ & High \\
$0,7>\langle g\rangle \geq 0,3$ & Middle \\
$\langle g\rangle<0,3$ & Low \\
\hline
\end{tabular}

\section{Result and Discussion}

This research results in increased students' science process skills during the application of computer-based scaffolding assisted by PhET simulation in the basic physics practicum course. Students' science process skills increase based on the results of the average calculation of each indicator. The results of this increase can be seen in Figure 2. In more detail, the increase was tested based on the $\mathrm{N}$-gain from the title of practicum 1 (magnetic electricity) to the title of practicum 2 (parallel capacitor series), from the title of practicum 2 (parallel capacitor series circuit) to the title practicum 3 (parallel resistor series), and practicum 1 (magnetic electricity) to practicum 3 (parallel resistor series). The results of the $\mathrm{N}$-gain test can be seen in Table 4.

The decline in science process skills only occurs in the indicators of carrying out experiments between the second (parallel capacitor series) and third (parallel resistor series) practicum. The decrease was -0.02 in the low category. This decrease is relatively small when compared to the increase in the achievement of indicators carrying out experiments in the medium category between the first practicum (magnetic electricity) and the second (parallel capacitor series circuit) with a value of 0.41 . 


\section{At-Taqaddum}

Vol. 13 No. 1 (2021) Pg. 21-38

Figure 2. Average Achievement of Science Process Skills Indicators
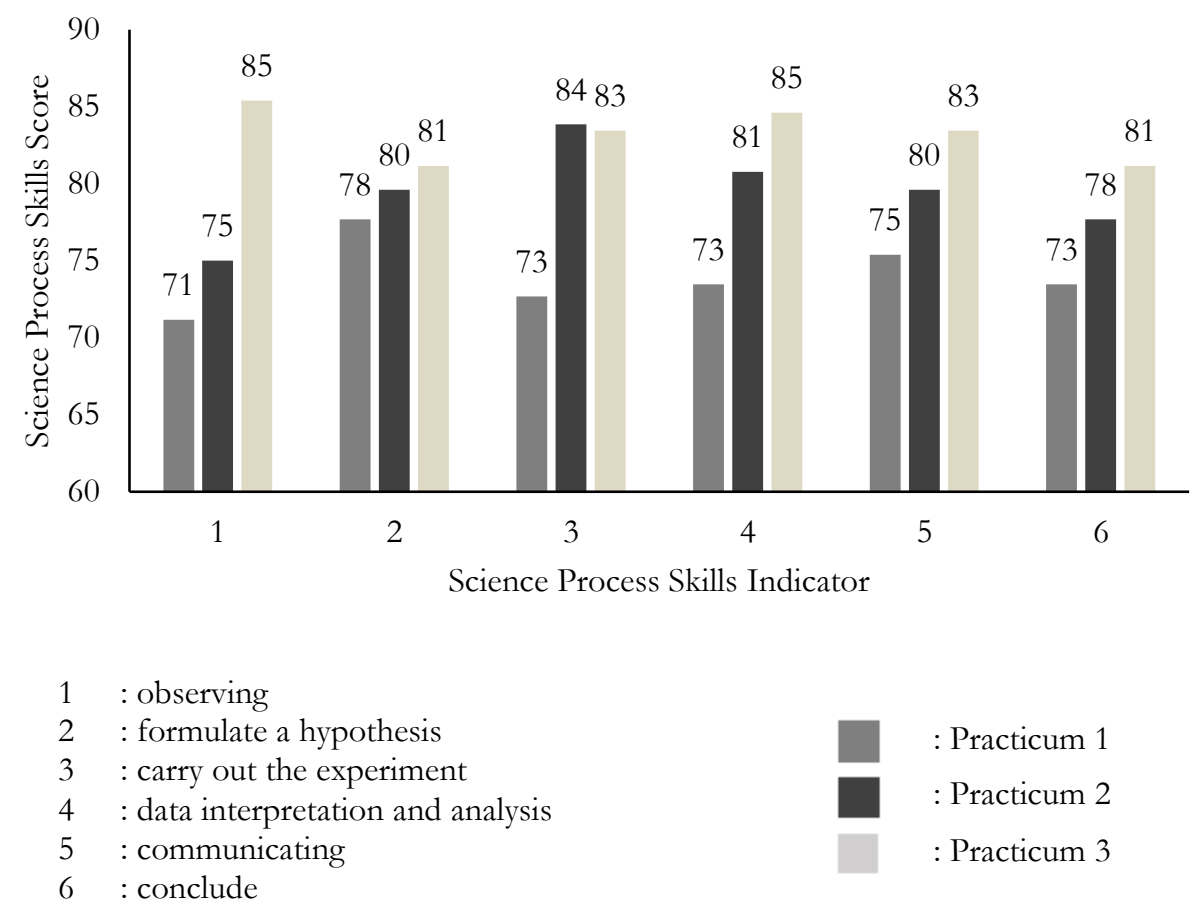

Table 4.

N-Gain of Student Science Process Skills

\begin{tabular}{|c|c|c|c|c|}
\hline No & $\begin{array}{l}\text { Science Process } \\
\text { Skills Indicator }\end{array}$ & Practicum 1 to 2 & Practicum 2 to 3 & Practicum 1 to 3 \\
\hline \multirow[t]{2}{*}{1} & observe & 0.13 & 0.42 & 0.49 \\
\hline & & Low Category & Medium Category & Medium Category \\
\hline \multirow[t]{2}{*}{2} & formulate a hypothesis & 0.09 & 0.28 & 0.34 \\
\hline & & Low Category & Low Category & Medium Category \\
\hline \multirow[t]{2}{*}{3} & carry out experiments & 0.41 & -0.02 & 0.39 \\
\hline & & Medium Category & Low Category Drop & Medium Category \\
\hline \multirow[t]{2}{*}{4} & Data interpretation & 0.28 & 0.20 & 0.42 \\
\hline & and analysis & Low Category & Low Category & Medium Category \\
\hline \multirow[t]{2}{*}{5} & communicate & 0.17 & 0.19 & 0.33 \\
\hline & & Low Category & Low Category & Medium Category \\
\hline \multirow[t]{2}{*}{6} & conclude & $0.16^{\circ}$ & 0.16 & 0.29 \\
\hline & & Low Category & Low Category & Low Category \\
\hline
\end{tabular}

\section{Science Process Skills Observing}

There was an increase in students' scientific process skills on the indicators of observing with a low category in the first practicum (magnetic electricity) to 
the second practicum (parallel capacitor series circuit), the medium category in the second practicum (parallel capacitor series circuit) to the third practicum (parallel resistor series circuit), and the medium category when viewed from the first practicum (magnetic electricity) to the third practicum (parallel resistor series circuit). In general, scaffolding can be applied to improve observation skills (Young and Bender-Slack 2011). However, observation is an initial step in experimental activities so it needs to be strengthened (Darmaji et al. 2018). The initial level of providing scaffolding by lecturers is environmental provision. In this stage, the lecturer prepares various learning resources, learning media, explains how to use PhET simulation, and displays practical tools in real laboratories. This information is used to allow students to observe real practical tools and corresponding virtual practicum tools. In the first practicum, observing indicators can be low compared to the achievement of the second and third practicums. This is because students are not used to interacting with PhET simulation media.

\section{Science Process Skills Formulating Hypotheses}

The indicator of hypothesis formulation also increased with a low category from the first practicum (magnetic electricity) to the second practicum (parallel capacitor series circuit). The low category is from the second practicum (parallel capacitor series circuit) to the third (parallel capacitor series circuit). Series resistor circuit), and its category, whereas if viewed from the first practicum (magnetic electricity) to the third practicum (parallel resistor circuit). Formulating hypotheses is an important indicator because it involves students thinking about the relationships and interrelationships between variables tested through practicum (Maison et al., 2019). All sources, information, and data provided by lecturers at level 1 environmental provision and level 2, namely explaining, are used as provisions processed in the thought process to formulate hypotheses before carrying out the practicum.

\section{Science Process Skills Carrying Out Experiments}

The indicator for carrying out experiments has increased with a moderate category in practicum 1 (magnetic electricity) to practicum 2 (parallel capacitor series circuit). On the other hand, the title of practicum 2 (parallel series of capacitors) to practicum 3 (series of parallel resistors of resistors) has decreased in the low category. When viewed from the title of practicum 1 (magnetic electricity) to practicum 3 (parallel resistor series), the indicators carrying out experiments have increased in the medium category. The decrease that occurred was due to the higher level of difficulty in the third practicum (parallel resistor series) compared to the first (magnetic electricity) and second (parallel capacitor series) practicum. The arrangement of the practicum sequence from easy to difficult follows the principle of Zone of Proximal Development (ZPD) used as the basis for applying the scaffolding approach. ZPD is the distance between the ability to complete tasks independently and the ability to complete tasks with the help of others (McDevitt 
and Ormrod 2014). In the first and second practicums, students did not experience assembling components and laboratory equipment used independently. While in the third practicum, students are required to assemble components and practicum tools independently.

\section{Science Process Skills Data Interpretation and Analysis}

The title of practicum 1 (magnetic electricity) to the title of practicum 2 (parallel series of capacitors) and the title of practicum 2 (series of parallel capacitors) to the title of practicum 3 (series of parallel resistors), indicators of data interpretation and analysis have increased in the low category. From the first practicum (magnetic electricity) to the third practicum (parallel resistor series circuit), the interpretation and analysis of the data have increased in the medium category. Interpretation and analysis are indicators of critical thinking skills (Hunaepi et al. 2020; Farcis 2019). Thus, increasing critical thinking skills also affects improving skills on indicators of interpretation and data analysis on science process skills. The scaffolding approach has improved critical thinking skills in physics learning (Ferty et al. 2019; Koes, Pradana, and Suwasono 2020). Following the study results, namely, improvement of data interpretation and analysis indicators after learning with computer-based scaffolding assisted by PhET simulation. Level 2 restructuring is the stage of feedback and confirmation from the lecturer on the report results, including interpretation and data analysis that students have carried out.

\section{Science Process $\quad$ Skills Communicating}

Communicating indicators have increased with a low category in the title of practicum 1 (magnetic electricity) to the title of practicum 2 (parallel capacitor series), the low category in the title of practicum 2 (parallel capacitor series) to the title of practicum 3 (parallel resistor series circuit), and medium category from practicum title 1 (magnetic electricity) to practicum title 3 (parallel resistor series circuit). Communicating is conducted at level 2 reviewing, namely at the opportunity to see, touch, and explain concepts based on practicum results under student perceptions. The stage is continued with restructuring which consists of lecturer assistance in confirmation and feedback on student perceptions. This restructuring is the location of the scaffolding given to improve science process skills in communicating indicators. Communicating is manifested in the form of writing a practicum report. Writing a practicum report requires scientific writing skills. Scaffolding is implemented in learning to improve scientific writing skills (Mardiani, Supeno, and Maryani 2018).

\section{Concluding Science Process Skills}

The indicator concludes an increase in the low category in practicum 1 (magnetic electricity) title to practicum 2 (parallel capacitor circuit). The low category in practicum 2 (parallel capacitor circuit) becomes practicum 3 (parallel resistor series). The lowest category is seen from practicum 1 (magnetic electricity) to practicum 3 (parallel resistor series). The conclusion indicator is the only indicator 
that experienced a low increase when viewed from the first practicum (magnetic electricity) to the last practicum (parallel resistor series circuit). The conclusion indicator lies at the last level, namely developing conceptual thinking. This level is the highest in scaffolding, which includes the stages of developing students' conceptual thinking. Students conclude the concept of physics based on the results of the practicum carried out and relate it to contextual phenomena in everyday life. Scaffolding can improve understanding of science concepts and mastery of physics concepts (Isrokatun et al., 2019; Jufriadi, Ayu, and Pratiw, 2019).

Computer-based scaffolding assisted by PhET simulation to Improve Science Process Skills

Computer-based scaffolding assisted by PhET simulation was implemented for six meetings with three different practicum titles. The first practicum is magnetic electricity, the second is a seriesparallel capacitor circuit, and the third is a series-parallel resistor circuit. Each practicum title is carried out in two meetings following the application matrix of computer-based scaffolding assisted by
PhET Simulation and aspects of student science process skills in Table 1 . According to the Zone of Proximal Development (ZPD) principle, practicum titles are arranged from easy to difficult level. Zone of Proximal Development (ZPD) is the distance between students' ability to complete assignments independently and with the help of lecturers (McDevitt and Ormrod 2014). The position of the Zone of Proximal Development (ZPD) see Figure 3.

The ability of students to complete assignments independently is called the Level of Actual Development. In contrast, the ability of students to complete assignments with assistance from lecturers is called the Level of Potential Development. The distance between the two levels is the Zone of Proximal Development (ZPD). Scaffolding is implemented in this area to assist students in completing tasks that cannot be completed independently. This pattern occurs gradually to complete the task's difficulty level starting from the easiest to the most complex level. The level of scaffolding pattern given in learning can be seen in Figure 4.

\section{Figure 3.}

The Difficulty of the Tasks and the Location of the Zone of Proximal Development

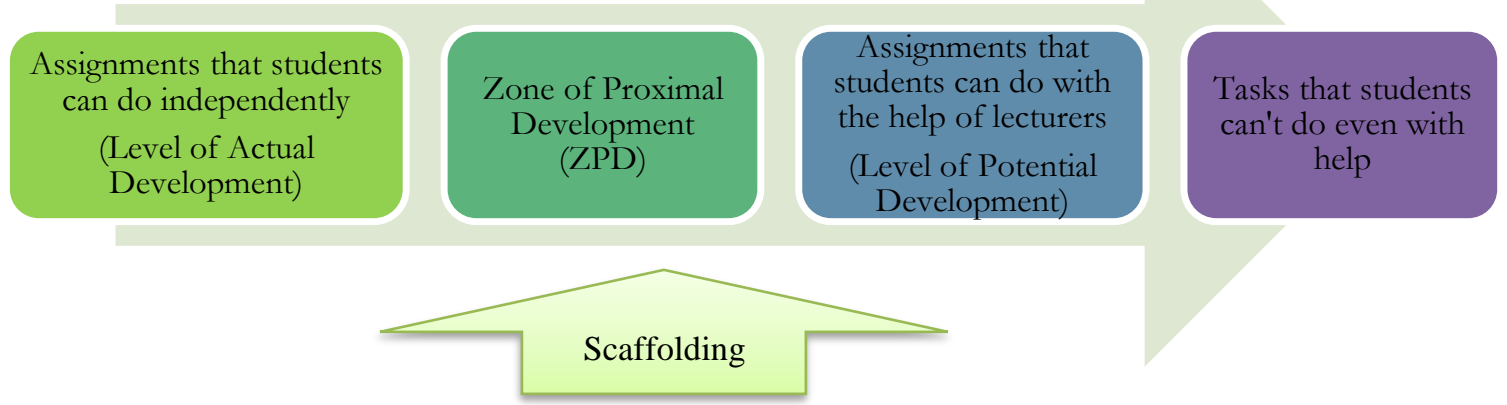


Figure 4.

Scaffolding Level Pattern in Learning

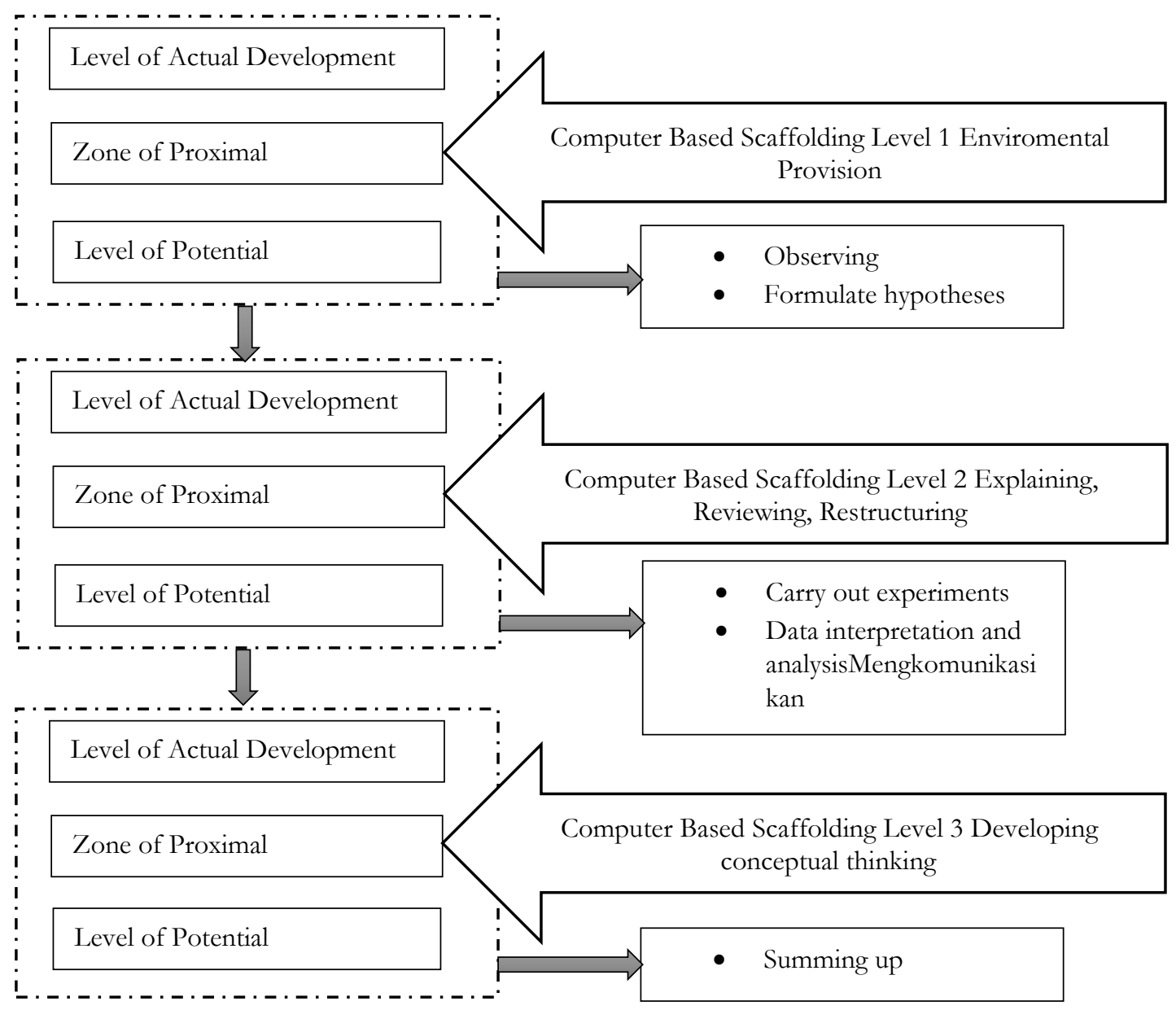

Level 1 scaffolding is the environmental provision, consisting of the provision of media and learning resources. This level is successful in developing students' science process skills in observing and formulating hypotheses. The lecturer explains the PhET simulation program, features, and menus that can be accessed in the practicum title that will be practiced. In the PhET simulation menu, lecturers can also provide introduction videos about various tools in the natural laboratory. The use of instructional video media affects science process skills (Cahyono, Sutarto, and Mahardika 2017). More specifically, the provision of videos can improve the ability to process information (Widiani, Darmawan, and Ma'mur 2018). The ability to process information is the main ability needed during the observation stage and formulating hypotheses. Thus, the provision of media and learning resources is an aid to students in the process of observing and formulating hypotheses. 
Level 2 Explaining, Reviewing, and Restructuring is carried out by explaining, reviewing, and restructuring. This level develops student skills in carrying out experiments, interpreting and analyzing data, and communicating (Dasilva et al. 2019). Explaining that lecturers are directly interacting with students by providing simple tutorials or simple examples of assembling tools. Reviewing, students are allowed to come into direct contact with the virtual laboratory space. Students carry out practicum independently by assembling these tools independently.

Furthermore, students interpret and analyze data based on the results of the practicum obtained and communicate it in a practicum report. This explaining and reviewing stage serves as an aid to students to improve their science process skills, namely carrying out experiments, interpreting and analyzing data, and communicating. The lecturer carries out restructuring by interpreting the concepts put forward by students and explaining them in a better and orderly language.

Level 3 is developing conceptual thinking, namely, developing conceptual thinking. This level is successful in improving students' science process skills in concluding indicators. Regarding the previous level, restructuring coupled with conceptual development carried out by giving more abstract assignments to students. The problems given are related to everyday life. Students develop their concepts based on the practicum results to analyze solutions to problems given by the lecturer. Concept understanding is closely related to science process skills (Magfirah, Hidayat, and Mahanal 2019). Summarizing is one of the abilities that are part of high- order thinking skills. The application of android-based scaffolding can improve high-order thinking skills (Dasilva and Suparno 2019). Thus, computer-based scaffolding assisted by PhET simulation has been successfully implemented in the Learning of Basic Physics II Practicum to improve science process skills.

Implementing the scaffolding approach in the practical implementation using PhET simulation can gradually improve students' science process skills. The increase that occurs between one practicum activity to the next is categorized as low. Although the increase is relatively low, it is continuously increasing. From the first practicum activity to the last practicum activity, the increase in science skills is categorized as moderate. The provision of scaffolding levels can train science process skills to make students more skilled in carrying out practicals. These skills include observing, formulating hypotheses, carrying out experiments, interpreting and analyzing data, communicating, and drawing conclusions. Computer-based scaffolding assisted by PhET simulation can be used as a solution in dealing with students' low science process skills during online learning. Computer-based scaffolding assisted by PhET simulation can also collaborate in offline learning with real practical implementation in the laboratory.

\section{Conclusion}

The application of computer-based scaffolding assisted by PhET simulation in basic physics practicum courses encourages student process skills. All indicators experienced an increase in students' science process skills, namely observing 0.49 (medium category), 


\section{At-Taqaddum}

Vol. 13 No. 1 (2021) Pg. 21-38

formulating hypotheses 0.34 (medium category), carrying out experiments 0.39 (medium category), data interpretation and analysis 0.42 (medium category), communicating 0.33 (medium category). Category), and a conclusion of 0.29 (low category). It is based on N-gain from the first practicum to the third practicum. Although there has been an increase in all indicators of science process skills, there is a challenge for further research, namely how to improve science process skills in the conclusion indicators to be equivalent to improvements in other science process skills indicators.

\section{References}

Belland, Brian R. 2017. Instructional Scaffolding in STEM Education. Instructional Scaffolding in STEM Education. London: Springer. https://doi.org/10.1007/978-3-31902565-0.

Brian, Reiser, and Tabak Iris. 2014. Scaffolding. The Cambridge Handbook of the Learning Sciences, Second Edition. Cambridge University Press. https://doi.org/https://doi.org/10. 1017/CBO9781139519526.005.

Cahyono, Bayu Angga Dwi, S Sutarto, and I Ketut Mahardika. 2017. "Model Pembelajaran REACT (Relating,Experiencing, Applying,Coo perating, Transfering) Disertai Media Video Kejadian Fisika Terhadap Keterampilan Proses Sains Dan Hasil Belajar Siswa Dalam Pembelajaran Fisika Di SMA." Jurnal Edukasi 4 (3): 20.

https://doi.org/10.19184/jukasi.v4i3 .6155 .
Darmaji, Darmaji, Dwi Agus Kurniawan, Ai Suryani, and Ayu Lestari. 2018. "An Identification of Physics PreService Teachers' Science Process Skills Through Science Process SkillsBased Practicum Guidebook." Jurnal Ilmiah Pendidikan Fisika Al-Biruni 7 (2): 239-45.

https://doi.org/10.24042/jipfalbirun i.v7i2.2690.

Darmaji, Dwi Agus Kurniawan, Astalini, Febrina Rosa Winda, Heldalia, and Lia Kartina. 2020. "The Correlation Between Student Perceptions of the Use of E- Modules with Students, Basic Science Process Skills." Jurnal Pendidikan Indonesia 9 (4): 719-29. https://doi.org/10.23887/jpiundiksha.v9i4.28310.

Dasilva, Beatrix Elvi, Heru Kuswanto, Insih Wilujeng, and Jumadi. 2019. "SSP Development with a Scaffolding Approach Assisted by PhET Simulation on Light Refraction to Improve Students' Critical Thinking Skills and Achievement of Science Process Skills." Journal of Physics: Conference Series 1233 (1). https://doi.org/10.1088/17426596/1233/1/012044.

Dasilva, Beatrix Elvi, and Suparno. 2019. "Development of the Android-Based Interactive Physics Mobile Learning Media (IPMLM) to Improve Higher Order Thinking Skills (HOTS) of Senior High School Students." Journal of Physics: Conference Series 1397 (1): 659-81.

https://doi.org/10.1088/17426596/1397/1/012010.

Dwi, Briliannur, Aisyah Amelia, Uswatun 
Hasanah, and Abdy Mahesha Putra. 2020. "Analisis Keefektifan Pembelajaran Online Di Masa Pandemi Covid-19." Jurnal Pendidikan Guru Sekolah Dasar 2 (1): 3.

Farcis, Fenno. 2019. "Profil Keterampilan Berpikir Kritis Mahasiswa Pendidikan Fisika Universitas Palangka Raya Dalam Proses Analisis Artikel Ilmiah." Jurnal Jejaring Matematika Dan Sains 1 (1): $52-58$. https://doi.org/10.36873/jjms.v1i1. 137.

Ferty, Zera Nadiah, Insih Wilujeng, Jumadi, and Heru Kuswanto. 2019. "Enhancing Students' Critical Thinking Skills through Physics Education Technology Simulation Assisted of Scaffolding Approach." Journal of Physics: Conference Series 1233 (1). https://doi.org/10.1088/17426596/1233/1/012062.

Fitriyanto, Syarif, Fahmi Yahya, Prodi Pendidikan Fisika, Universitas Samawa, and Kabupaten Sumbawa. 2019. "Pengaruh PBL Berpendekatan Multipel Representasi Terhadap Keterampilan Berpikir Kritis Dan Keterampilan Proses Sains Dalam Pembelajaran Fisika." QUARK: Jurnal Inovasi Pembelajaran Fisika Dan Teknologi 2 (1): 19-23.

Hake, Richard R. 1999. "Analyzing Change/Gain Scores." AERA-DAmerican Educational Research Association's Division, Measurment and Research Methodology: Dept." Of Physics Indiana University.

Haryadi, R., and H. Pujiastuti. 2020. "PhET Simulation Software-Based Learning to Improve Science Process
Skills." Journal of Physics: Conference Series 1521

(2).

https://doi.org/10.1088/1742-

6596/1521/2/022017.

Haryati, Tri, Diah Riski Gusti, Muhammad Haris Effendi Hasibuan, and Muhammad Rusdi. 2020. "The Development of Scaffolding in Inquiry-Based Learning to Improve Students' Science Process Skills in The Concept of Acid and Base Solution." JKPK Jurnal Kimia Dan Pendidikan Kimia) 5 (2): 211-21. https://doi.org/10.20961/jkpk.v5i2. 42420 .

Hunaepi, Laras Firdaus, Taufik Samsuri, Endang Susantini, and Raharjo. 2020. "Implementasi Worksheet Inkuiri Terintegrasi Kearifan Lokal Untuk Meningkatkan Keterampilan Berpikir Kritis Mahasiswa." Bioscientist: Jurnal Ilmiah Biologi 8 (1): 158-69.

Isrokatun, I., D. Anggita, B. S. Purwono, C. Sunaengsih, and A. A. Syahid. 2019. "Scaffolding in Conceptual Science." Journal of Physics: Conference Series 1402

https://doi.org/10.1088/1742-

(4). 6596/1402/4/044079.

Jufriadi, A., H.D. Ayu, and H.Y. Pratiw. 2019. "Developing E-Scaffolding Integrated with E-Assessment to Improve Student'S Mastery of Concept" 287 (Icesre 2018): 176-79. https://doi.org/10.2991/icesre18.2019.37.

Koes, S. H., S. D.S. Pradana, and P. Suwasono. 2020. "Integration Conceptual Scaffolding in the Group Investigation: Its Influence on Students' Critical Thinking Skills." 


\section{At-Taqaddum}

Vol. 13 No. 1 (2021) Pg. 21-38

Journal of Physics: Conference Series 1481

(1). https://doi.org/10.1088/17426596/1481/1/012132.

Lee, Kiyoung, Junhyuk Heo, and Jaeyoung Park. 2019. "Development and Application of Cognitive Scaffolding Tools for Enhancing the Integrated Science Process Skills of High School Students." Journal of the Korean Association for Science Education 39 (4): 545-62.

Lestari, Mega Yati, and Nirva Diana. 2018. "Keterampilan Proses Sains (KPS) Pada Pelaksanaan Praktikum Fisika Dasar I." Indonesian Journal of Science and Mathematics Education 1 (1): 50-54. http://ejournal.radenintan.ac.id/inde x.php/IJSME/article/view/2474/18 28.

Magfirah, Ainun, Arif Hidayat, and Susriyati Mahanal. 2019. "Penggunaan Media Audiovisual Pada Model Inkuiri Terbimbing Terhadap Keterampilan Proses Sains Dan Penguasaan Konsep IPA." Jurnal Pendidikan 4 (1): 96-103.

Maison, Darmaji, Dwi Agus Kurniawan, Astalini, Utari Prisma Dewi, and Lia Kartina. 2019. "Analysis of Science Process Skills in Physics Education Students." ISSN 2502-3632 (Online) ISSN 2356-0304 (Paper) Jurnal Online Internasional \& Nasional Vol. 7 No.1, Januari - Juni 2019 Universitas 17 Agustus 1945 Jakarta 23 (2): 197-205. https://doi.org/http://dx.doi.org/1 $0.21831 /$ pep.v23i2.28123.

Mardiani, Anisa, Supeno, and Maryani. 2018. "Lembar Kerja Siswa (LKS) Berbasis Inkuiri Disertai Scaffolding Prompting Question Untuk
Meningkatkan Keterampilan Menulis Ilmiah Siswa Pada Pembelajaran Fisika Di SMA." Seminar Nasional Pendidikan Fisika "Aktualisasi Peran Generasi Milenial Melalui Pendidikan, Pengembangan Sains, Dan Teknologi Dalam Menyongsong Generasi Emas 2045" 3 (2): 162-66.

McDevitt, Teresa $M$, and Janne Ellis Ormrod. 2014. Child Development and Education. New Jearsey: Pearson Education.

Noor, Yusmaniar Afifah, Ngurah Made Darma Putra, Sunyoto Eko Nugroho, Putut Marwoto, Budi Naini Mindyarto, Suharto Linuwih, Sugiyanto Sugiyanto, et al. 2020. "Praksis Praktikum Fisika Mode Daring : Studi Kasus Pembelajaran Di SMA / MA Jawa." Unnes Physics Education Journal 9 (3): 276-83.

Rohman, Agus, and Trise Nurul Ain. 2019. "Tanggung Jawab Dan Keterampilan Proses Sains Mahasiswa: Profil Dan Rancangan Pembelajaran Untuk Melatihkannya." Berkala Ilmiah Pendidikan Fisika 7 (3): 196-204. https://doi.org/10.20527/bipf.v7i3. 6991.

Rustaman, Nuryani. 2005. Strategi Belajar Mengajar Biologi. Malang: Universitas Negeri Malang.

Samosir, Sofia Christine, and Lidia Gurning. 2020. "Relationship Between the Perception and Skills of Student Basic Science Process in the Use of M-Module in Basic Physics Practicum." Jurnal Pena Sains 7 (1): 8 17.

https://doi.org/10.21107/jps.v7i1.6 342. 
Saputri, Affa Ardhi, and Insih Wilujeng. 2017. "Development Physics." International Journal of Environmental and Science Education 12 (4): 729-45. http:// files.eric.ed.gov/fulltext/EJ11 44754.pdf.

Sholikah, Ta'imul, Anisa Fitri Mardhotillah, Lisawati Achmadi Indriyani, Vela Ayu Wulandari, Permata Sari Kuraesin, Nur Laily Sa'adatus Abadiyah Al-Khotim, Muhammad Yuda Irjiananto, et al. 2020. "Studi Eksplorasi Kegiatan Praktikum Sains Saat Pandemi Covid19." Indonesian Journal of Science Learning 1 (2): 67-75. http://jurnalftk.uinsby.ac.id/index.p $\mathrm{hp} / \mathrm{IJSL}$.

Siahaan, Matdio. 2020. "Dampak Pandemi Covid-19 Terhadap Dunia Pendidikan." Jurnal Kajian Ilmiah 1 (1): 73-80.

https://doi.org/10.31599/jki.v1i1.26 5.

Siswono, Hendrik. 2017. "Analisis Pengaruh Keterampilan Proses Sains Terhadap Penguasaan Konsep Fisika Siswa." Momentum: Physics Education Journal $1 \quad$ (2): 83. https://doi.org/10.21067/mpej.v1i2. 1967.

Syazali, Muhammad, Aisa Nikmah Rahmatih, and Nursaptini Nursaptini. 2021. "Profil Keterampilan Proses Sains Mahasiswa Melalui Implementasi SPADA Unram." Jurnal Pijar Mipa 16 (1): 103. https://doi.org/10.29303/jpm.v16i1 .2290 .

Utami, Tri, Jumadi, Insih Wilujeng, and Heru Kuswanto. 2019. "Subject
Specific Pedagogy Development with Scaffolding Approach Assisted by PhET Simulation on Momentum Conservation Law to Improve Students' Conceptual Understanding and Learning Independence." Journal of Physics: Conference Series 1233 (1). https://doi.org/10.1088/17426596/1233/1/012066.

Widiani, Lusiana Surya, Wawan Darmawan, and Tarunasena Ma'mur. 2018. "Penerapan Media Film Sebagai Sumber Belajar Untuk Meningkatkan Kemampuan Mengolah Informasi Siswa Dalam Pembelajaran Sejarah.” Factum: Jurnal Sejarah Dan Pendidikan Sejarah 7 (1): 123-32.

Wood, David, Jerome S. Bruner, and Gail Ross. 1976. "The Role of Tutoring in Problem Solving." Journal of Child Psychology and Psychiatry 17 (2): 89-100. https://doi.org/10.1111/j.14697610.1976.tb00381.x.

Wu, Chun Hui, You Shyang Chen, and Ta Cheng Chen. 2018. "An Adaptive ELearning System for Enhancing Learning Performance: Based on Dynamic Scaffolding Theory." Eurasia Journal of Mathematics, Science and Technology Education 14 (3): 903-13. https://doi.org/10.12973/ejmste/81 061.

Young, Teresa, and Delane Bender-Slack. 2011. "Scaffolding Pre-Service Teachers' Observations: Eye on the Future." Teaching Education 22 (3). https://doi.org/https://doi.org/10. 1080/10476210.2011.593166.

Yusro, Andista Candra, and Adi Purwito. 2021. "Modul Fisika Berbasis Augmented Reality Sebagai Alternatif 


\section{At-Taqaddum}

Vol. 13 No. 1 (2021) Pg. 21-38

Sumber Belajar Siswa." Jurnal Ilmiah

Pendidika Fisika 5 (1): 38-46.

Zulaeha, Zulaeha, I Wayan Darmadi, and Komang Werdhiana. 2014. "Pengaruh Model Pembelajaran Predict, Observe And Explain Terhadap Keterampilan Proses Sains
Siswa Kelas X Sma Negeri 1 Balaesang." JPFT Jurnal Pendidikan Fisika Tadulako Online) 2 (2): 1. https://doi.org/10.22487/j25805924 .2014.v2.i2.2771. 